\title{
Agama, Moral dan Etika: \\ Perspektif Dialektika dan IMPlikasinya \\ DALAM EKONOMI
}

Muhammad Djakfar

Dosen Fakultas Ekonomi Universitas Islam Negeri (UIN) Malang

\section{Abstract}

Religion, moral and ethics are institution which have the samelearning wisdom value and justice. They undergo dialectic in daily life. Otherwise, dialectic's result will be never meaningful without connected with contextual problem, such as economy. So that, in fact how is the dialectic implication in economy activities. Answering that question, thereare 2 patterns of thinking. First, Al-Ghozali's pattern which does emphasizes to theology strength than reason, because it based on AlQur'an and Hadist. This pattern is followed by YusufQardhawi, Mustaq Ahmad and M.Quraish Shihab. Second, a pattern directed by E.Kant uses critical power and sharp analytical. This pattern is followed by Weber, Pratley and Rowland.

For appearing the growth of epoch, both of patterns need to be energetic in order that they will be more optimally in guiding economy activities next. Because, however it is, economics' progress needs knowledge and spiritual power.

Keywords: religion, ethics, economy.

\section{A. Pendahuluan}

Zaman sekarang yang dikenal dengan sebutan era globalisasi telah didominasi oleh pesatnya perkembangan informasi (information), komunikasi (comunication) dan teknologi (technology). Keadaan ini telah membawa perubahan besar terhadap kehidupan masyarakat dalam banyak segi. Perubahan itu mengusung kemajuan yang luar biasa (spektakuler), sekaligus menimbulkan kegelisahan di kalangan orang banyak. Perkembangan ilmu pengetahuan dan teknologi telah menjadikan planet bumi serasa kian menyempit, seakan-akan sekatantar wilayah dan antar bangsa tidak lagi menjadi 
penghalang untuk melakukan komunikasi dan mengakses informasi yang begitu cepat. Manusia zaman dahulu yang begitu gelap dan terbatas pengetahuannya tentang ruang angkasa misalnya, kini mulai terkuak lebar dengan bantuan teknologi super canggih yang diciptakannya sendiri.

Semuanya itu telah membawa perubahan besar terhadap perilaku manusia yang menjadi wilayah kompetensi moral. Sekarang banyak orang mulai mempertanyakan kembali kompetensi, sekaligus peran dan kemampuan moral untuk mengantisipasi, mengatur dan mengendalikan moral masyarakat. Semakin hari perilaku masyarakat kian permissive, tidak submissive lagi dalam memegangi nilai moral dan etika. Bahkan nilai sakral agama sekalipun. Bila kita cermati secara jujur dan objektif, sikap-sikap seperti ini telah banyak merambah ke dalam berbagai ranah dan lini kehidupan masyarakat seperti sosial, hukum, budaya, ekonomi dan lain-lain.

Dalam menghadapi situasi yang demikian itu, muncul berbagai pertanyaan, masih mungkinkah kita merumuskan kembali norma-norma universal dalam moral, etika dan agama yang plural? Apabila mungkin, masihkah kita mempunyai niat baik untuk melaksanakan hasil rumusan itu, karena tanpa dukungan subjek pelaku, norma-norma itu tidak akan bermakna dalam kehidupan. Tentu saja pertanyaan ini hanya bisa dijawab dengan hati nurani, baik secara individual maupun kolektif. Dalam arti, perlu ada kesadaran individu maupun kolektif untuk mengfungsikan nilai-nilai altruis demi kepentingan manusia secara universal.

Agama, moral dan etika merupakan istilah, sekaligus entitas (entity) yang sudah begitu populer dalam kehidupan sehari-hari karena ketiganya dikenal sebagai sumber nilai untuk mengatur kehidupan manusia. Bahkan di kalangan ilmuwan telah menjadi komoditas kajian akademis yang sudah melembaga dan sudah lama berkembang. Sebagai institusi yang sama-sama mengajarkan nilai-nilai kebaikan, agama dan etika seharusnya saling mengisi (Saleh, 2003:5). Demikian pula dengan moral. Atau dengan kata lain, antara agama, moral dan etika seharusnya terjadi dialektika, yang satu mengisi yang lain.

Namun perlu kita pahami bahwa persoalan moralitas dan etika sebenarnya menyangkut persoalan 'cara berpikir' atau persoalan filsafat (Saleh, 2003:5). Dengan begitu, research question yang perlu dikedepankan 
adalah bagaimana filsafat memandang nilai-nilai yang mendialektika dari ketiga institusi yang berbeda tersebut dan bagaimana implikasinya terhadap ekonomi?

Sebagaimana kita ketahui bahwa filsafat adalah dunia spekulasi (Abdullah, 1997:147) dan perenungan (Jujun,1996:22). Perenungan yang spekulatif tak akan bermakna apa-apa tanpa dikaitkan ke dalam masalah kontekstual. Di antaranya adalah persoalan ekonomi. Karakteristik berpikir filsafat adalah bersifat mendasar dan spekulatif, di samping menyeluruh (komprehensif). Seorang ilmuwan tidak puas lagi mengenal ilmu hanya dari sudut pandang ilmu itu sendiri. Dia ingin melihat hakikat ilmu dalam konstelasi pengetahuan lainnya. Dia ingin tahu kaitan ilmu dengan moral. Kaitan ilmu dengan agama. Dia ingin yakin apakah ilmu itu membawa kebahagiaan kepada dirinya (Kattsoff, 1986:6). Inilah alasan mendasar mengapa diskursus ini juga ingin memahami bagaimana seharusnya implikasi hasil dialektika ketiga institusi itu dalam aktivitas ekonomi. Dengan pemahaman ini diharapkan kita bisa mengkonstruk sebuah etika yang ideal yang bersifat universal.Tujuannya adalah untuk memberikan pencerahan hasil perenungan filosofis terhadap dunia ekonomi yang bisa memberikan kesejahteraan kepada umat manusia.

\section{B. Agama, Moral dan Etika: Perspektif Dialektika}

Berbicara tentang moral dan etika asosiasi kita juga pada istilah akhlak. Dengan demikian ada tiga istilah yang menjadi sumber nilai kebajikan dan keadilan yang sudah dikenal dalam kehidupan sehari-hari, yaitu moral, etika dan akhlak. Hanya saja dua istilah pertama banyak dikenal dalam literatur filsafat Barat, sedangkan istilah yang ketiga banyak dikenal dalam literatur Islam, dalam kaitannya dengan masalah akhlak atau tasawuf.

Dari hasil penelitian penulis (Jujun,1996:20) dapat disimpulkan bahwa para ahli tidak membedakan secara substansial antara pengertian etika dan moral, sebagaimana bisa kita buktikan dalam literatur-literatur mereka. Bahkan bila kita bandingkan kedua istilah tersebut dengan istilah akhlak dalam literatur Islam, secara substansial juga tidak ada perbedaan. Persamaan itu karena ketiganya sama-sama mengandung ajaran kebajikan (wisdom), keadilan (justice) dan kejahatan (evil). 
Disamping itu dapat disimpulkan pula, paling tidak ada dua kategori pandangan tentang etika. Pandangan pertama menyatakan bahwa etika adalah independen (otonom), dalam arti bebas dari ikatan atau dominasi agama. Pandangan ini diwakili Nietzche. Sedangkan pandangan kedua menyatakan ada interelasi antara agama dan etika. Kelompok pandangan yang kedua ini, antara lain diwakilioleh Nielsen, Tillich. Niebuhr dan filosof Islam.

Nietzche mengemukakan bahwa peradaban Barat tidak lagi dapat menerima landasan religius untuk etika. Namun di sisi lain mereka mendukung nilai-nilai yang diturunkan dari tradisi Yahudi-Kristen. Hal ini menurutNietzche karena Tuhan sudah bukan lagi menjadifaktor motivator dalam peradaban. Tuhan telah menjadi sekedar obyek sejarah metafisik yang sudah mati, sisa-sisa dari takhayul primitif. Manusia sekarang tidak lagi membutuhkan Tuhan, kendati nilai-nilai yang diderivasi dari theisme masih dipercaya. Nietzche yakin bahwa sistem nilai yang semacam ini akan mudah roboh, dan harus ada sesuatu yang menggantikannya agar budaya Eropa tidak tenggelam dalam era nihilisme (Djakfar, 2004:16-17). Selanjutnya ia mengatakan, saat ini Tuhan dalam tradisi Yahudi dan Kristen telah mati dari hati dan pikiran manusia. Dan demokrasi dengan segala pernyataannya yang keliru bahwa semua orang adalah sejajar hanyalah merupakan manifestasi politik dan moralitas budak, dan karenanya harus ditolak (Stewart, 1980: 347).

Tidak demikian halnya dengan Nietzche. Menurut Nielsen, kendati ada yang berpendapat bahwa Tuhan telah mati dan etika dapat bersifat independen dari agama, mungkin akan sangat mengejutkan bagi para penganut Yahudi dan Kristen yang beriman agar berpikir dengan jernih dan mengkaji ulang masalah Tuhan yang mati dan menghayatinya dengan sungguh-sungguh, maka kehidupan akan tetap bermakna dan bermoral, dan bahkan moralitas akan memiliki tujuan yang rasional (Stewart, 1980: 349). Selanjutnya ia menyatakan ada perbedaan antara moralitas sekuler dengan moralitas berdasarkan agama. Moralitas sekuler yang sempurna dapat diderivasikan dari dua prinsip yang dapat digunakan untuk membuktikan prinsip rasional yang sangat jauh dari pertimbanganpetimbangan religius. Sedangkan moralitas religius bersifat lebih sederhana karena ia membutuh-kan hanya satu prinsip saja. Selain itu pendukung 
moralitas religius menyatakan bahwa manusia merupakan makhluk Tuhan dan karenanya merupakan nilai yang tak terhingga (Stewart,1980:355).

Pemikir lain, dalam hal ini Tillich, mengemukakan dua elemen dalam agama yang keduanya penting yaitu kemaafan (forgiveness) dan regenerasi (regeneration). Kemaafan adalah kondisi yang dapat diterima, sekalipun kita mungkin tidak terlalu menerima. Keberterimaan ini juga mencakup menerima diri sendiri. Regenerasi berarti mengatasi pemisahan antara siapa kita sesungguhnya dengan siapa kita seharusnya. Menurut Tillich, cinta mentrasformasikan moralisme kewenangan menjadi sebuah moralitas beresiko. Cinta di sini merujuk pada cinta dengan makna kekuatan regenerasi, bukan pada emosi. Justifikasi ketuhanan tidaklah mengutuk, namun lebih cenderung mentransformasi. Dan transformasi ini, yang berbasis moralitas, adalah kekuatan cinta. Cinta adalah kekuatan untuk mengatasi pemisahan dan keganjilan (gap), terutama keganjilan dalam diri kita sendiri (Stewart, 1980:356).

Dalam hubungannya dengan kebutuhan etika bagi agama, Niebuhr menyatakan bahwa fanatisme dan keputusasaan merupakan dua bahaya kembar yang mengahadang kita ketika kita puas hanya dengan pendekatan mengenai cita-cita moral (Stewart,1980:371).

Gary E. Kessler dalamsebuah wacananya: How Are Religion and Morality Related?, menegaskan bahwa:

Hubungan antara agama dan moralitas adalah kompleks.Pada satu sisi, kita bisa menggolongkannya sebagai hal yang bersifat psikologis. Sedangkan di sisi lain, kita bisa memahami hubungan ini secara sosiologis. Demikian pula hubungan agama dan moralitas dapat juga dipahami melalui term logika dan filsafat.

Hubungan kompleks antara agama dan moralitas tersebut dengan segala macam persoalan pokok dan argmen yang mengitari adalah hubungan yang muncul ketika kita mempertimbangkan validitas teori ajaran yang bersifat ketuhanan tentang etika. Bagaimanapun ini adalah sebuah klaim yang problematis (Stewart,1980:379)

Menurut Anthony O'Hear pengakuan kita tentang sesuatu, sebagai kehendak Tuhan. Tuhan berkehendak pada yang baik karena Ia adalah baik (Kessler:269) Dalam Islam, menurut Seyyed Hossein Nasr, seluruh kehidupan Muslim dipengaruhi oleh panduan-panduan etika, sebagaimana 
Islam juga menolak pandangan yang melegitimasiadanya domain dari segala aspek kehidupan -baik itu sosial, politis, atau ekonomis- berada di luar panduan nilai-nilai etis (Anthony,1984:71).

Adanya dikotomi pandangan yang memisahkan agama dari etika sebagaimana dikemukakan Nietzche di atas membawa implikasi pada posisi agama di satu pihak, dengan posisi etika di lain pihak, bahkan interelasi antara keduanya. Dengan begitu bila dilihat dari pandangan autonomy, agama dan etika berada pada posisi sendiri-sendiri, sehingga keduanya seakan tak pernah menyapa, yang satu kepada yang lain.

Sebaliknya, bila dilihat dari perspektif interelasi, yang menyatakan ada hubungan erat antara agama dan etika, maka keduanya saling mengisi dan berdialektika dalam menanamkan nilai-nilai kebajikan secara universal.

Untuk lebih jelasnya tentang dialektika itu di sini perlu dikemukakan pendapat M. Amin Abdullah:

Perlu dibedakan apa yang disebut dengan 'moral' dan apa yang disebut dengan 'etika'. Tidak hanya orang awam, tetapi banyak dikalangan cendekiawan mengaburkan ketajaman distinsi antara keduanya. Pada umumnya orang cenderung untuk menyamaratakan begitu saja antara keduanya, bahkan tidak sedikit yang mengacaukannya dengan istilah 'toto kromo', 'sopan santun', 'budi pekerti' (dalam ruang lingkup adat istiadat) atau dengan istilah 'akhlak' (dalam ruang agama). Untuk kepentingan ketajaman analisis What is going on, kita memang perlu melihat secara lebih dalam distinsi antara keduanya

Titik tekan 'moral' adalah aturan-aturan normative yang perlu ditanamkan dan dilestarikan secara sengaja baik oleh keluarga, lembaga-lembaga pendidikan, lembagalembaga pengajian. Dengan begitu, moral adalah suatu aturan atau tata cara hidup yang bersifat normatif yang sudah ikut serta bersama kita seiring dengan umur yang kita jalani. Dari kecil kita sudah mengenal aturan-aturan itu. Pengajaran moral begitu banyak sumber mata airnya. Bisa dari agama (Islam, Kristen, Katolik, Budha dan Hindu), bisa dari adat istiadat (orang tua, masyarakat, lingkungan sekitar), bisa dari negara (pendidikan moral Pancasila), bisa juga dari ideologi-ideologi lain seperti liberalisme, individualisme, kolektivisme, pragmatisme, hedonisme, dan lain sebagainya.

Pengajaran dan penanaman moral sudah berjalan sepanjang kehidupan sejarah manusia. Agaknya tidak ada masyarakat di belahan bumi ini yang hidup tanpa sistem pengajaran moral (Nasr, 2003:115). 


\section{Lebih tegas lagi Abdullah menyatakan:}

Jika kita boleh menarik garis batas antara moral dan etika maka 'moral' adalah aturanaturan normatif (dalam bahasa agama Islam disebut akhlak) yang berlaku dalam suatu masyarakat tertentu yang terbatas oleh ruang dan waktu. Penerapan tata nilai moral dalam kehidupan sehari-hari dalam masyarakat tertentu menjadi bidang kajian antropologi, sedangkan 'etika' adalah bidang garap filsafat,. Realitas moral dalam kehidupan masyarakat yang terjernihkan lewat studi kritis (critical studies) adalah wilayah yang dibidangi oleh 'etika'. Jadi, studi kritis terhadap moralitas menjadi wilayah etika, sehingga moral tidak lain adalah obyek material daripada etika (1997:167).

\section{Selanjutnya ia menyatakan:}

Berbeda dari etika, yakni filsafat moral, maka akhlak lebih dimaksudkan sebagai suatu 'paket' atau 'produk jadi' yang bersifat normatif-mengikat, yang harus diterapkan dalam kehidupan sehari-hari seorang Muslim. Akhlak atau kadang disebut dengan tasawuf adalah seperangkat tata nilai keagamaan yang harus direalisasikan dalam kehidupan sehari-hari, tanpa perlu mempertanyakan dan mengunyah secara kritis terlebih dahulu.

Akhlak atau moralitas adalah merupakan seperangkat tata nilai yang 'sudah jadi' dan 'siap pakai' tanpa dibarengi, bahkan terkesan menghindari studi kritis, sedang 'etika' justru sebaliknya bertugas untuk mempertanyakan secara kritis rumusan-rumusan masa lalu yang sudah menggumpal dan mengkristal dalam lapisan masyarakat (1997:147).

M. Amin Abdullah dalam karyanya yang lain: Antara Al-Ghazali dan Kant Filsafat Etika Islam, membuat dikotomi tentang etika, yaitu etika rasional dan etika religius (1997:220). Dikotomi ini terjadi karena Abdullah bertolak dari pandangan Al-Asy'ariyah yang didukung Al-Ghazali yang lebih condong ke dalam pemikiran teologi, dan pandangan Mu'tazilah yang sejalan dengan pemikiran Kant yang bercorak rasional (filosofis).

Untuk menempuh jalan tengah dari dikotomi itu, Abdullah mengemukakan pendapatnya:

Penulis menggolongkan pendekatan yang bercorak independen, baik teologis maupun filosofis, sebagai "pendekatan dikotomis dan reduksionis". Dengan kata lain, mengatakan bahwa etika hanya dapat dilandaskan kepada wahyu seperti yang ditekankan Al-Ghazali adalah konsepyang tidak memadai. Ini tidaklah berarti 
bahwa norma-norma wahyu itu tidak memadai, memainkan konsepsi itu sendiri yang tidak memadai. Meskipun boleh jadi tepat secara emosional dan psikologis, ia tidaklah memadai, tidak secara intelektual. Sebaliknya, mengatakan bahwa etika harus berlandaskan pada 'rasio' saja, tampaknya merupakan penyederhanaan yang berlebihan. Karena rasio, seperti ditegaskan Kant sendiri di lain tempat adalah terbatas dalam kapasitasnya untuk menangkap dan memahami esensi dan dunia noumenal.

Hanya "kerja sama" antara "etika wahyu" dan "etika rasional" yang akan dapat menyelamatkan manusia dari keadaan terperangkap dalam keterpecahan kepribadian. Penulis meyakini bahwa dalam perubahan sosial yang cepat dan taransformasi budaya yang hebat adalah tugas kesejarahan yang besar untuk membangun pendekatan terhadap wacana etika yang ideal seperti itu (Fakhry, 1996:48-49).

Mencermati uraian di atas sampailah pada kesimpulan bahwa kita sepakat ketiga institusi: agama, moral dan etika, merupakan sumber nilai kebajikan. Agama merupakan dasar atau sumber ajaran moral, kendati juga ada yang berpendapat bahwa moral itu otonom dari ajaran agama. Moral yang bersumber dari agama inilah yang kemudian disebut etika religius atau dikenal sebagai ajaran akhlak dalam Islam. Etika religius inilah yang akan memandu kehidupan manusia guna mencapai kebahagiaan yang dicita-citakan. Hanya saja apakah rumusan-rumusan nilaimoralyang sudah mengkristal itu masih sesuai dengan perubahan sosial yang begitu cepat dan dahsyat, maka inilah bidang garap etika rasional yang kemudian juga dikenal dengan filsafat moral.

Setelah memahami proses dialektika sebagaimana di atas, kita akan mencoba memahami bagaimana seharusnya etika itu -dalam kapasitasnya sebagai ilmu atau filsafat moral- berimplikasi dalam aktivitas ekonomi sebagaimana yang telah disumbangkan oleh para ahli.

\section{Implikasi dalam Ekonomi: Perenungan Filosofis}

Sebelum ini telah dikatakan bahwa realitas moral dalam kehidupan masyarakat yang terjernihkan lewat studi kritis (critical studies) adalah wilayah etika. Dalam hal ini etika mengkritisi moralitas, sehingga moral tidak lain adalah obyek material daripada etika rasional yang menghasilkan perenungan filosofis. Jika yang dimaksud moralitas kehidupan itu merupakan 
wilayah ekonomi, maka moral ekonomi inilah yang perlu kita pikirkan secara kritis agar bisa menghasilkan moralitas yang bermakna bagi kehidupan.

Kalau kita kaitkan dengan konteks Indonesia dewasa ini yang tengah mamacu pembangunan ekonomi tapi justeru mengapa masih banyak pelanggaran moral yang berakibat merugikan keuangan negara. Anehnya pelanggaran itu terus berkelanjutan dengan pelaku banyak dari kalangan intelektual dan birokrat yang seharusnya menjadi uswah bagi masyarakat. Kendati demikian karena diskursus ini berpretasi pada dataran filosofis maka datadata yang berkaitan dengan masalah ekonomi sengaja tidak diprioritaskan.

Perenungan filosofis dimaksudkan mengadakan refleksi untuk memahami sesuatu yang paling dasar, unsur-unsur atau syarat-syaratnya yang paling hakiki, untuk dapat memahami semua fakta atau segi yang ada. Dengan melalui perenungan filosofis ini kita akan memahami bahwa inti aktivitas ekonomi adalah perilaku. Perilaku pelaku-pelaku ekonomi, bisa rumah tangga-rumah tangga, bisa perusahaan-perusahaan dan bisa pemerintah (Koento Wibisono, 1983:101).

Berbicara tentang subyek pelaku berarti berbicara tentang manusia. Karena di tangan manusialah segala aktivitas perekonomian bisa dilaksanakan dan dikembangkan. Inilah yang dimaksud peran subyek aktif dalam etika oleh M. Amin Abdullah (Sukirno,1997:37). Manusia merupakan satu kesatuan fisio-psikis yang di dalam psikologi dikenal sebagai makhluk monodualis. Bahkan ada yang mengatakan satu kesatuan fisiopsikis-rohani (Abdullah,1997:213). Manusia mempunyai ciri-khas yang terbentuk dari faktor-faktor rohaniah, psikologik dan fisiologik dalam lingkungan budaya dan masyarakat lingkungannya. Karena itu, manusia seharusnya dipahami sebagai manusia yang sejahtera jiwa dan raganya, dengan segi-seginya religius, kultural, sosial dan biologik.

Melalui perenungan filosofis seperti di atas, jelaslah kiranya bahwa pengertian "manusia" bukanlah sesuatu yang sederhana, yang begitu saja dapat di skemakan, diarahkan atau diramalkan secara "positif" menurut hukum-hukum ilmu pengetahuan. Atau dengan kata lain betapa sulitnya memahami manusia. Memang ilmu pengetahuan dapat mengantarkan kita kepada pemahaman fakta secara obyektif melalui pengkajian atau pengujian 
atas dasar metode yang disediakan. Namun kita sering kurang menyadari bahwa kebenaran ilmiah positif bukanlah kebenaran yang utuh dan lengkap. Disinilah peran filsafat sangat diharapkan dan ditunggu-tunggu.

Sebagaimana diketahui dalam dunia filsafat, kita dihadapkan kepada masalah-masalah dasar yang tidak akan terpecahkan, dalam arti kata bahwa ada masalah-masalah yang sejak dahulu hingga kini tetap sama yang tidak pernah dapat kita berikan jawabannya yang satu dan sama. (Wibisono, 1983: 102). Misalnya, di bidang ontologi, 'apakah ada itu', 'apakah dan siapakah manusia itu' dan lain sebagainya. Jawaban atas masalah-masalah seperti itu, secara filosofis tidak pernah satu, karena masing-masing jawaban dilandasi dengan keyakinan ontologik yang telah dijadikan pilihannya, menurut perasaan dan keyakinannya masing-masing. Karena itu, bagaimana gagasan dan perwujudan dari nilai-nilai kualitatif seperti "human dignity, security, justice, equity" akan sangat ditentukan oleh pilihan keyakinan ontologik. Terutama dalam menentukan pendirian dalam menghadapi masalah "apa dan siapa manusia", karena pada akhirnya sang manusia inilah yang akan bertindak selaku subyek atau pendukung nilai-nilai kualitatif (Wibisono,1983:103).

Untuk mengetahui lebih jauh bagaimana seharusnya implikasi etika dalam ekonomi agar menjadi perilaku subyek pendukungnya, antara lain bisa kita lihat bagaimana pengaruh etika Protestan terhadap semangat kapitalisme sebagaimana dijelaskan Max Weber dalam karyanya The Protestan Ethic and The Spirit of Capitalism:

Untuk dapat memahami hubungan antara ide-ide keagamaan yang bersifat fundamental dan Protestanisme asketis dengan maksimnya bagi perilaku ekonomi seharihari, maka perlu untuk memeriksa dengan teliti seluruh tulisan-tulisan semacam itu yang secara pasti berasal dari praktik-praktik ministerial (kependetaan).

\section{Selanjutnya Weber menyatakan:}

Ekonomi kapitalistik masa sekarang adalah suatu kosmos raksasa tempat di mana manusia dilahirkan dan menghadapkan dirinya kepada manusia, setidak-tidaknya sebagaiindividu, sebagai suatu tatanan segala hal yang tidak berubah yang di dalamnya dia harus hidup. Hal ini memaksa setiap individu, sejauh dia terlibat di dalam sistem hubungan pasar, untuk menyesuaikan diri dengan aturan-aturan tindakan kapitalistik. 
Pengusaha pabrik yang pada jangka panjang bertindak berlawanan dengan normanorma ini akan lenyap dari dunia ekonomi, seperti seorang pekerja yang tidak dapat atau tidak mau menyesuaikan diri dengan norma-norma itu pasti akan terlempar ke jalan tanpa memiliki pekerjaan.

Kapitalisme sekarang, yang telah mendominasi kehidupan perekonomian, mendidik dan memilih insan-insan ekonomi yang dibutuhkannya melalui suatu proses "survival of the fittest" dalam bidang ekonomi (Weber, 2003:226).

Dengan filosofi yang seperti itu pada kenyataannya telah terbentuk sebuah bangunan norma dalam perkonomian di Barat, di samping berhasil juga membangun etos kerja di kalangan pengikut Protestan sehingga banyak mencetak mereka sebagai kapitalis di banding pengikut Katolik. Hal ini dipertegas oleh Weber sendiri bahwa para pemimpin bisnis dan pemilik modal maupun para karyawan perusahaan yang mempunyai kemampuan (skill) tinggi ataupun para staf terdidik, baik secara teknis maupun komersial ternyata kebanyakan adalah orang Protestan.

Lain lagi dengan etika bisnis Jepang yang filosofinya nampaknya banyak diwarnai ajaran agama mereka: Shinto. Perilaku masyarakat Jepang, tanpa kecuali dalam hubungannya dengan bisnis terbaca dari pemikiran:

1. Orang-orang Jepang percaya bahwa keselarasan di permukaan dipertahankan dengan segala daya upaya;

2. Di dalam situasi konflik, orang-orang Jepang akan berupaya untuk menghindari malu, bagi mereka sendiri dan seringkali juga bagi lawannya;

3. Orang-orang Jepang enggan menghadapi orang lain dalam konflik terbuka;

4. Rasa memiliki kewajiban merupakan pendorong yang kuat bagi tingkah laku orangorang Jepang;

5. Kesamaan latar belakang dan kebiasaan yang saling dijaga, memungkinkan mereka saling mamahami, hanya dengan melalui sedikit atau tanpa isyarat sekalipun;

6. Bagi orang-orang Jepang, kerjasama di antara semua anggota lebih didahulukan daripada tanggung jawab, otoritas, dan inisiatif perorangan;

7. Orang-orang Jepang percaya bahwa keputusan yang didasarkan hanya pada logika semata jelas mencerminkan kedunguan dan ketidakpekaan terhadap sifat kemanusiaan;

8. Orang-orang Jepang menilai keselarasan di atas kebenaran. Mereka tidak akan mempertanyakan tentang hal-hal yang mungkin dapat menciptakan suasana yang kurang enak (Rowland,1992:6). 
Itu semua dimaksudkan untuk sekedar memperkenalkan pada kita beberapa norma tingkah laku yang mendasar, yang dapat berfungsi sebagai bagian yang tak terpisahkan dari kultur bangsa Jepang. Sekaligus memperluas wawasan pemahaman kita sebanyak mungkin tentang keaneka ragamanetika bisnis di berbagai belahan bumi yang seringkali partikularistik, di samping bermuatan yang universal. Dengan filosofi itu kita bisa melihat kemajuan ekonomi Jepang yang bisa kompetitifdengan negara-negara maju di dunia, baik dengan Amerika maupun negara-negara di Eropa. Ini disebabkan karena mereka begitu kuat mematuhi etika, sekaligus memacu diri sebagai manusia pekerja (workholic) di antara bangsa-bangsa di dunia.

Peter Pratley dalam sebuah bukunya yang berjudul The Essence of Business Ethics mengemukakan etika dalam aktivitas bisnis. Dalam bukunya ini ia menyatakan bahwa etika hanya mempelajari satu jenis pertimbangan normatif: pertimbangan moral diperlukan dalam praktek moral setiap hari. Etika deskriptif hanya menjelaskan perilaku dan pertimbangan moral. Sedangkan etika normatif merumuskan secara filsafat teori-teori yang masuk akal dengan suatu dorongan yang memberikan petunjuk. Sebuah teori etika normatif tidak hanya memberi gambaran bia ia menilai praktek yang ada berdasarkan standar moral eksplisit yang menunjukkan apa yang harus dilakukan dalam suatu situasi. Etika normatif adalah suatu cabang ilmu filsafat yang mempelajari pertimbangan moral. Tujuannya adalah menilai perilaku moral masa lalu dengan menggunakan standar-standar moral yang telah didefinisikan dengan jelas, dan mençoba merumuskan petunjuk-petunjuk untuk situasi yang baru. Dengan menguraikan standar-standar moral yang jelas, etika dapat memberikan kerangka pemikiran yang menyeluruh daripada pokok persoalan moral. Jadi, etika normatif adalah suatu refleksi filsafat pada moralitas konvensional (Pretley,1997:33).

Etika bisnis menganut metode-metode dan tujuan etika normatif terhadap kebutuhan-kebutuhan spesifik suatu jenis pertimbangan moral tertentu, yaitu pertimbangan yang menyangkut kebijakan bisnis, norma dan nilai bisnis. Etika ini menilai dan menentukan standar-standar moral yang sesuai dengan lingkungan spesifik dalam masyarakat modern, yaitu bisnis. 
Dikatakan bahwa tugas utama etika bisnis diarahkan untuk mencari cara menyelaraskan kepentingan strategis perusahaan dengan permintaan moral. Kepentingan strategis tidak seluruhnya terpisah dari perasaan moral, tetapi di dalam kepentingan-kepentingan itu terkandung akibat-akibat yang bermanfaat secara moral yang harus dinilai secara hati-hati (Pretley, 1997: 84).

Untuk memperjelas keselarasan antara kepentingan perusahaan dengan permintaan moral itu, Pratley mengangkat sebuah kasus: Pencurian kecil-kecilan sumbangan pasien di Rumah Sakit Oranjeoord di Harlingen dalam musim semi 1994. Pada akhir Juni, kamera video telah merekam perbuatan ahli syaraf satu-satunya di rumah sakit tersebut yang dengan berjingkat mendekati kotak donasi dan mengambil uang kertas dengan menggunakan pinsetnya. Pada mulanya para anggota dewan rumah sakit keheranan dan geram justru mengapa hal itu bisa terjadi pada diri seorang spesialis mereka yang terhormat. Ia telah melakukan kejahatan kecil. Sekarang mereka sedang menghadapi suatu dilema besar, dengan dimensi strategis. Memecat orang ini hampir pasti akan berakibat serius untuk masa depan jangka pendek rumah sakit ini. Mereka sedang berada dalam tahap negosiasi dengan mitra yang jauh lebih besar, yaitu Pusat Medis Leeuwarden (MCL). Akibat berikutnya, paling tidak 20 orang akan kehilangan lapangan kerjanya, dan para pasien akan diharuskan pergi ke rumah sakit Leeuwarden yang berjarak 25 kilometer dari sana.

Dalam keputusannya, dewan rumah sakit tidak memecat ahli syaraf tersebut. Alasan-alasannya dinyatakan secara terbuká karena ada kepentingan strategis yakni tetap bertahannya klinik syaraf dan menghindari pemutusan hubungan kerja (PHK) bagi 20 staf perawat. Keputusan itu diambil kendati menanggung akibat moral yang berat.

Mustaq Ahmad dalam disertasinya yang berjudul Business Ethics in Islam berupaya untuk mengeksplorasi, menganalisa, dan mensintesa keputusan-keputusan yang relevan berdasarkan Al-Qur'an, agar dapat menghasilkan teori yang dibutuhkan tentang etika. Penemuan hasil kerja ini kemungkinan akan berfungsi sebagai dasar untuk membangun sebuah teori yangkuatdan meyakinkan, yangdapat diaplikasikan di setiap situasi, sekarang maupun yang akan datang. 
Tidak diragukan lagi bahwa legalitas bisnis dibahas oleh Al-Qur'an Eksposisi sintetik ajaran Al-Qur'an diharapkan akan membantu kita dalam menggambarkan prinsip-prinsip dasar dari etika bisnis Al-Qur'an. Ketaatan pada prinsip-prinsip ini akan memberikan jaminan keadilan dan keseimbangan yang dibutuhkan dalam bisnis dan akan menjaga aktivitas komersial pada koridor yang benar (Mustaq Ahmad, 2001:3). Untuk bisa mencapai tujuan itu, Ahmad telah mencoba menggali secara mendalam ayat-ayat Al-Qur'an sehingga dapat mencakup setiap keputusan atau saran yang dihasilkan dalam masalah ini. Norma-norma ideal yang bersumber dari kitabullah inilah yang harus menjadi pertimbangan setiap pelaku bisnis di manapun dan kapanpun mereka berada.

Yusuf Qardhawi, seorang ulama besar millinium ketiga ini tidak ketinggalan ikut memperjelas bagaimana implikasi etika dalam ekonomi, dalam sebuah karyanya yang berjudul Daurul Qiyam wal Akhlaq fil Iqtishadil Islami.

Menurut Qardhawi poros risalah nubuwah Nabi Muhammad SAW adalah akhlak. Karena itu Islam telah mengimplikasikan antara mu'amalah dengan akhlak, seperti jujur, amanah, adil, ihsan, berbuat kebajikan, silaturrahmi dan sayang menyayangi. Dikaitkan pula akhlak pada aspek hidup -menyeluruh, sehingga tidak ada pemisahan antara ilmu dengan akhlak, antara politik dengan akhlak, antara ekonomi dengan akhlak, antara perang dengan akhlak, dan lain sebagainya. Dengan demikian, akhlak menjadi daging dān urat-nadi kehidupan Islam (Qardhawi, 1995:4) yang harus memandu segala aktivitas seorang Muslim.

Jika kita berbicara tentang akhlak dalam ekonomi Islam, maka tampak secara jelas di hadapan kita empat nilai utama, yaitu: rabbaniyyah (ketuhanan), akhlak, kemanusiaan dan pertengahan (Qardhawi, 1995:23). Nilainilai ini mencerminkan keunikan dalam ekonomi Islam yang tidak dimiliki oleh sistem ekonomi manapun di dunia.

Nilai-nilai tersebut merupakan karakteristik syariat Islam yang kaffah, sempurna dalam segala dimensinya. Atas dasar karakteristik itu ekonomi Islam jelas berbeda dengan sistem ekonomi konvensional karena ia adalah sebuah sistem ekonomi ilahiah, ekonomi humanistis, ekonomi moralistis dan ekonomi moderat. Makna dan nilai-nilai pokok yang empat ini mempunyai dampak terhadap seluruh aspek ekonomi, baik dalam masalah 
produksi, konsumsi, sirkulasi maupun distribusi. Semua itu terpola oleh nilainilai tersebut, karena jika tidak, niscaya keislaman itu hanya sekedar simbol tanpa makna.

Sejalan dengan perkembangan zaman, kecenderungan bisnis sekarang kian tidak memperhatikan masalah etika. Akibatnya, sesama pelaku bisnis sering bertabrakan kepentingannya, bahkan saling membunuh. Kondisi ini menciptakan pelaku ekonomi yang kuat kian merajai. Sebaliknya, yang kecil makin terlindas. Keadaan seperti ini mengancam pertumbuhan dan perkembangan dunia bisnis. Menghadapi kecenderungan tersebut, Al-Qur'an relatif banyak memberikan garis-garis dalam kerangka penambahan bisnis yang menyangkutsemua pelaku ekonomi tanpa membedakan kelas (Shihab, 1997:4).

Apabila kenyataan memang demikian adalah tugas para ahli agar terus aktif menawarkan konsep-konsep nilai yang bisa dijadikan panduan melalui perenungan mendalam. Perlu disadari, bagaimanapun nilai moral tidak lepas dari ikatan ruang dan waktu yang selalu berubah tiada henti. Perubahan itu membawa konsekuensi kurang relevannya nilai-nilai moral untuk bisa dijadikan pedoman baku. Nah, dalam kondisi seperti ini peran etika rasional maupun etika religius sangatlah diharapkan untuk bisa merumuskan kembali nilai-nilai yang sesuai dengan perputaran zaman.

\section{Kesimpulan}

Bertolak dari uraian di atas, akhirnya dapat ditarik kesimpulan bahwa proses dialektika telah menghasilkan etika rasional yang kemudian disebut dengan filsafat moral yang berfungsi untuk mengkritisi, mengevaluasi dan mengkonstruk kembali nilai moral yang telah berlaku. Hal ini perlu dilakukan karena bisa jadi nilai lama itu tidak relevan lagi dengan perubahan sosial, budaya, dan ekonomi yang begitu cepat dan dahsyat.

Implikasi etika dalam aktivitas ekonomi bisa dipahami dari tawaran para ahli.Untuk ini bisa dikategorikan ke dalam dua pola. Pertama,yakni pola Al-Ghazali yang lebih menekankan pada kekuatan teologis ketimbang rasio. Polaini ditempuh oleh YusufQardhawi, MustaqAhmaddan M. Quraish Shihab yang lebih banyak menggali dari Al-Qur'an maupun Hadits (sumber 
naql). Pemikiran yang ditawarkan tidak lebih daripada inti ajaran yang sudah dianggap baku dan mapan sehingga mengurangi daya kritis filosofisnya. Sebaliknya pola kedua, yang mengikuti pola E. Kant yang justru mengandalkan kekuatan rasiosemata. Pola ini nampak pada corak pemikiran Weber, Pratley dan Rowland dengan daya kritis dan analisis yang begitu mendasar dan tajam dalam menawarkan ide-idenya. Terutama sekali seperti yang dilakukan oleh kedua ahli yang pertama, yaitu Weber dan Pratley.

Sekalipun demikian kekuatan kedua pola tersebut perlu disinergikan atau disintesakan, karena menafikan kekuatan salah satunya berarti suatu kenaifan. Khususnya dalam menghadapi perkembangan zaman yang membutuhkan pedoman moral yang tidak saja merupakan hasil perenungan filosofis, namun juga yang bersumber dari agama (religi).

Wallahu a'lam bisshawab.

\section{Daftar Pustaka}

Abdullah, M. Amin, Antara Al-Ghazali dan Kant, Filsafat Etika Islam (Penerjemah Drs. Hamzah, M.Ag), Jakarta: Mizan, 2002 , Falsafah Kalam di Era Postmodemisme, Yogyakarta: Pustaka Pelajar, 1997

Ahmad, Mustaq, Business Ethics in Islam, Pakistan: The International Institute of Islamic Thought, 2001

Bertens, K., Etika, Jakarta: Penerbit PT Gramedia Pustaka Utama, 1997.

Djakfar, Muhammd, Religion and Ethics: Eksplorasi Posisi Agama dan Etika dan Hubungan Antara Keduanya (Kajian dari Aspek Filsafat), Makalah Seminar Kelas untuk Mata Kuliah Filsafat Agama Program Doktor Program Pascasarjana IAIN Sunan Ampel Surabaya Semester Genap 2003/2004

Fakhry, Majid., Etika dalam Islam (Penerjemah Zakiyuddin Baidhawy), Yogyakarta: Pustaka Pelajar bekerjasama dengan Pusat Studi Islam UMS, 1996 
Kattsoff, Louis O., Elements of Philosophy, New York: The Ronald Press Company, 1986

Kessler, Gary E., Philosophy of Religion: Toward a Global Perpective, California: Wadsworth Publishing Company

Nasr, Seyyed Hossein, Islam: Agama, Sejarah dan Peradaban (Penerjemah Koes Adiwidjajanto, MA), Surabaya: Risalah Gusti, 2003

O'Hear, Anthony, Experience, Explanation and Faith: An Introduction ti the Philosophy of Religion, London: Routledge \& Kegan Paul, 1984

Pratley, Peter, The Essence of Business Ethics: Etika Bisnis (Penerjemah Gunawan Prasetio), Yogyakarta: Penerbit ANDI dan Simon \& Schuster (Asia) Pte.Ltd, 1997

Qardhawy, Yusuf, Daurul Qiyam wal Akhlaq fil Iqtishadil Islami, Kairo, Mesir: Maktabah Wahbah, 1995 M / 1415 H

Rowland, Diana, Etika Bisnis Jepang: Petunjuk Praktis Menuju Sukses Orang Jepang (Alih Bahasa Drs. Sahat Simamora, M.Sc), Jakarta: Bumi Aksara, 1992

Saleh, Fauzan, Filsafat Agama: Pokok-pokok Bahasan dalam Perkualiahan Filsafat Agama Program Doktor (S3) IAIN Sunan Ampel Surabaya Semester Gasal 2003-2004, Surabaya: tp. 2003

Shihab, M. Quraish, Etika Bisnis dalam Wawasan Al-Qur'an dalam Jurnal Kebudayaan dan Peradaban ULUMUL QUR'AN, edisi 3/NII/97

Stewart, David., Exploring the Philosophy of Religion, London: PrenticeHall, Unc, Englewood Cliffs, 1980

Sukirno, Sadono, Pengantar Teori Mikroekonomi, Jakarta: PT RajaGrafindo Persada, 1997

Suriasumantri, Jujun S., Filsafat Ilmu Sebuah Pengantar Populer, Jakarta: Pustaka Sinar Harapan, 1996

Suseno, Franz Magnis, Etika Dasar Masalah-masalah Pokok Filsafat Moral, Yogyakarta: Penerbit Kanisius, 1987

Vos, H. De, Pengantar Etika (Penerjemah Drs. Soejono Soemargono), Yogyakarta: PT Tiara Wacana Yogya, 2002 
Weber, Max, Etika Protestan dan Semangat Kapitalisme (Penerjemah Yusup Priyasudiarja), Pustaka Promethea, 2003

Wibisono, Koento, Arti Perkembangan Menurut Filsafat Positivisme Auguste Comte, Yogyakarta: Gajah Mada University, 1983 